\title{
Land use and topography influences on wildfire occurrence in northern Portugal
}

\author{
Miguel Carmo ${ }^{a}$, Francisco Moreira $^{\mathrm{a}, *}$, Pedro Casimiro $^{\mathrm{b}}$, Pedro Vaz $^{\mathrm{a}}$ \\ a Centre of Applied Ecology “Prof. Baeta Neves”, Institute of Agronomy, Technical University of Lisbon, Tapada da Ajuda, 1349-017 Lisbon, Portugal \\ ${ }^{\mathrm{b}}$ Departamento de Geografia e Planeamento Regional, Faculdade de Ciências Sociais e Humanas, Universidade Nova de Lisboa, Av. de Berna, 26-C, 1069-061, Lisboa, Portugal
}

\section{A R T I C L E I N F O}

\section{Article history:}

Received 5 November 2009

Received in revised form 21 June 2010

Accepted 3 November 2010

Available online 26 January 2011

\section{Keywords:}

Selection patterns

Landscape management

Fire risk

Mediterranean

\begin{abstract}
A B S T R A C T
Understanding the spatial patterns of wildfire ignition and spread has important implications for landscape planning for reducing fire hazard. In this paper we characterise the patterns of wildfire occurrence in 3 regions of northern Portugal, using selection ratio functions to evaluate the fire proneness of different land cover and topographic categories. For attaining this objective we characterised 1382 wildfires larger than 5 ha, which occurred in the years 1990-1991, according to land cover (10 categories), slope ( 5 categories) and aspect ( 5 categories) within which they occurred. For each fire, the use of the different land cover and topographic categories was compared with availability in a surrounding buffer. For land cover, fire proneness was much higher in shrublands, whereas agricultural areas and agro-forestry systems where less likely to burn. In terms of slope, steep slopes were more prone to fire. Differences in land cover in the different slope categories contributed to this result, although there was an overall slope effect on the fire proneness of all land cover types. In terms of aspect, only flat areas were less fire prone. Finally, there were regional variations in land cover susceptibility to fire, but these did not occur for slope or aspect. In terms of landscape planning these results suggest that the more effective fuel breaks should be implemented in areas with agricultural crops in flat slopes.
\end{abstract}

(C) 2011 Elsevier B.V. All rights reserved.

\section{Introduction}

Disturbances play a fundamental role in shaping the structure and dynamics of the landscape (Turner and Dale, 1990). On one hand, the spatial propagation of the disturbances is a function of the abundance and arrangement of disturbance-susceptible habitats (Turner et al., 1989). On the other hand, landscape patterns are determined by the frequency, intensity and extension of the disturbance (Pickett and White, 1985; Krumel et al., 1987). Considering that fire is one of the main disturbances affecting Mediterranean landscapes, understanding how landscape structure affects the spatial spread of wildfires is a key issue for understanding their ecological implications and the role they play in landscape dynamics (Moreira et al., 2009). Furthermore, this knowledge has profound implications for sustainable landscape planning (e.g. Hann and Bunnell, 2001; Leitão and Ahern, 2002).

The start of a fire and its spread are the result of a complex interaction between ignition sources, weather conditions, vegetation and topography (Mermoz et al., 2005). This work analyses the relation between wildfires and these two last factors. Vegetation plays a key role as fuel structure, load and moisture content

\footnotetext{
* Corresponding author. Tel.: +351 213653333; fax: +351 213623493.

E-mail addresses: miguelccarmo@gmail.com (M. Carmo),fmoreira@isa.utl.pt (F. Moreira), pjcc.casimiro@sapo.pt (P.Casimiro), zasvaz@gmail.com (P. Vaz).
}

depend on vegetation type (Turner and Dale, 1991; Bajocco and Ricotta, 2008; Moreira et al., 2001, 2009). Topography directly affects fire behaviour by promoting the radiant energy transfer from the fire line in the direction of the higher slopes (Rothermel, 1983). Indirectly, topography also affects fire by creating different microclimates which influence the moisture content of fuels, the air temperature, as well as the biogeographic distribution of plant species (Heyerdahl et al., 2001; Mermoz et al., 2005). Topography and land cover are often linked, e.g. agricultural areas may be preferentially located on lowlands, and forests in slopes, which may hinder the understanding of the ultimate drivers of fire spread.

In Portugal, a set of socio-economic and environmental conditions leads to a landscape very prone to fire. The climate is characterised by dry summers, and large fires occur when the Azores anticyclone spreads through central Europe linked to another high pressure centre over the Mediterranean, which at the surface leads to an abnormal advection of hot dry air masses crossing the peninsula centre coming from Northern Africa (Pereira et al., $2005,2006)$. The natural vegetation is typically evergreen, resistant to drought and pyrophytic (Nunes et al., 2005). Additionally, in the last decades socioeconomic and demographic evolution in rural areas led to agricultural land abandonment and subsequent shrubland encroachment, as well as the afforestation of former agriculture fields. In both cases a higher accumulation of fuels is generated which leads to a higher risk of fire (Silva, 1990; Rego, 1992; Moreira et al., 2001, 2009). Because of these factors, wildfire 


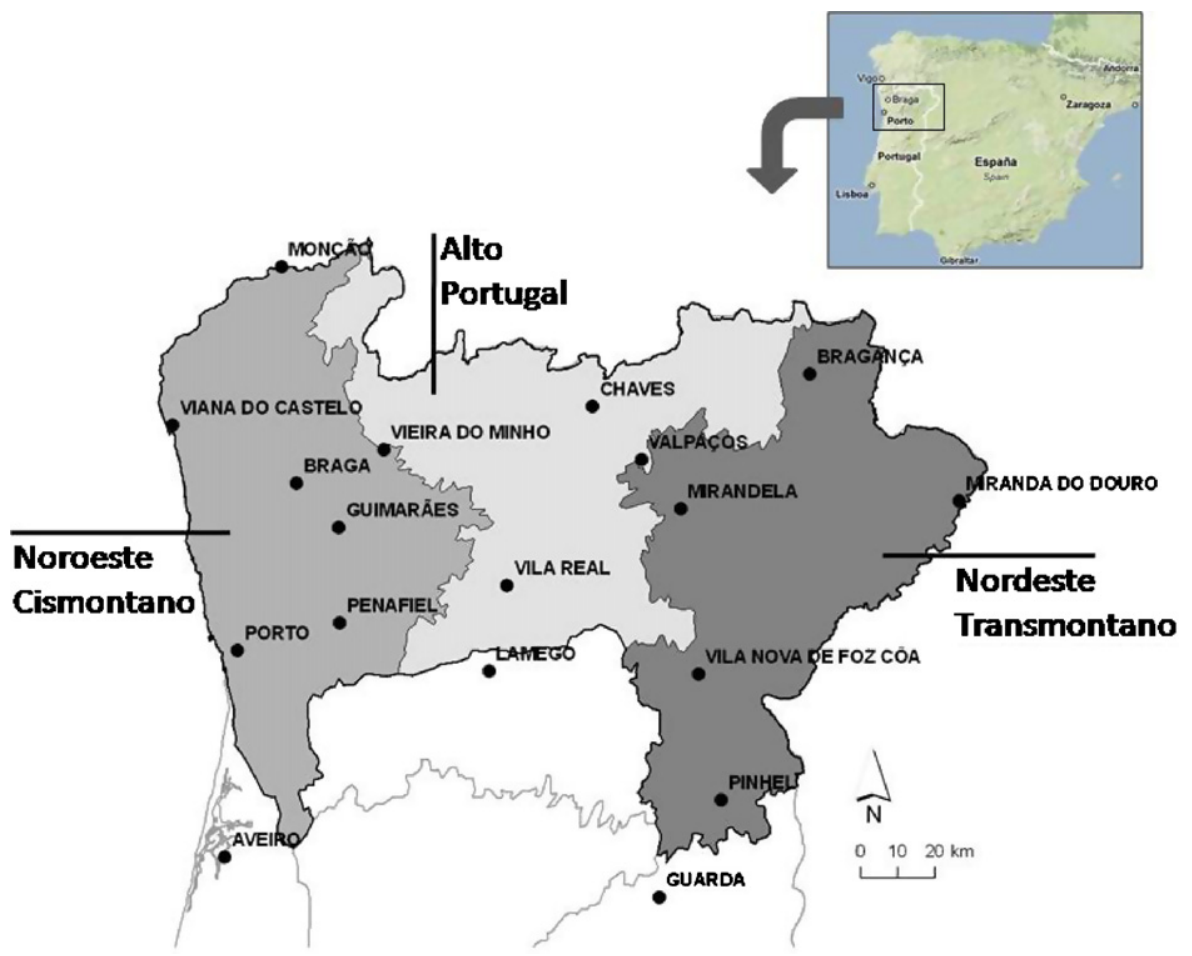

Fig. 1. Map of the study area with the three ecological regions. The location of main cities is also shown.

occurrence in Portugal has risen in the last few decades (Moreira et al., 2001; Pereira et al., 2006). The mean annual area burned in Portugal in the period 1980-2004 slightly exceeds $1 \%$ of the total area of the country, which is, by far, the highest fire incidence in Europe (Nunes et al., 2005). Most of these fires (over 95\%) are ignited by people (Catry et al., 2009).

In contexts such as the one of Portugal, the analysis and understanding of fire ignition and spread patterns is important to inform landscape planning and management practices designed to reduce fire risk and hazard at the landscape scale, in particular, the location and characteristics of fuelbreaks. That is the aim of this study, which, by characterising selection patterns of wildfires occurring in northern Portugal during 1990 and 1991, addresses the following specific questions: (a) which land cover types and topographic features (slope and aspect) are more fire prone in this region?; (b) are there regional variations in fire patterns with respect to land use and topography?; (c) are the relationships between fire occurrence and topography related to land use?

\section{Materials and methods}

\subsection{Study area}

The study area occupies a total surface of $557 \mathrm{~km}^{2}$ in northern Portugal, and is confined by the latitudes $40^{\circ} 38^{\prime}$ to $42^{\circ} 09^{\prime} \mathrm{N}$ and longitudes $6^{\circ} 11^{\prime}$ to $8^{\circ} 53^{\prime} \mathrm{W}$. It is divided in three ecological regions Noroeste (NW) Cismontano, Alto Portugal and Nordeste (NE)Transmontano - based on climatic, geologic and topographic features (Albuquerque, 1985) (Fig. 1). The resident population is ca. 3.2 millions people. The Douro river drainage basin occupies around $70 \%$ of the region. It is a mountainous area, with the altitude ranging from sea level to $1548 \mathrm{~m}$ in Serra do Gerês, with an average value of ca $500 \mathrm{~m}$.

In bioclimatic terms, most of the territory is Mesomediterranean and Supramediterranean (Rivas-Martínez, 1987; Rivas-Martínez et al., 2002). The average annual precipitation varies between ca.
$400 \mathrm{~mm}$ in the eastern part, below altitudes of $400 \mathrm{~m}$, and over $2800 \mathrm{~mm}$ in the north-western ridges. The average annual temperature varies between $7.5^{\circ} \mathrm{C}$ and $16^{\circ} \mathrm{C}$; the average maximum is around $22-32{ }^{\circ} \mathrm{C}$; the average minimum is around $0-8{ }^{\circ} \mathrm{C}(\mathrm{APA}$, 1974). In phytogeographic terms, the region is divided by the Eurosiberian region, Galicia-Portuguese sector, in the west half, with characteristic species being Quercus robur, Acer pseudoplatanus, Pyrus cordata and Ilex aquifolium. The eastern part is occupied by the Mediterranean region, Carpetano-Ibérico-Leonesa Province with Castanea sativa, Quercus faginea subsp. Faginea, Quercus pyrenaica, Quercus suber, and Quercus ilex as characteristic species (Costa et al., 1998).

The study area has a high frequency of wildfires in Portugal (Pereira et al., 2006). This region also shows a strong climate transition where the Atlantic influence meets the Mediterranean, leading to strong spatial gradient of temperature and precipitation. This produces a heterogeneous landscape suitable for testing the existence of regional variations in fire selection patterns.

\subsection{Land cover map}

The base map was a 1990 land cover map for Portugal (scale 1:25,000) developed by the Instituto Geográfico Português (IGP, 1990). As that map is incomplete for a few parts of Portugal (ca 5\%), the gaps were filled with CORINE land cover data (scale 1:100,000) (IGP, 1988), based on 1986 Landsat imagery (Moreira et al., 2009). The legends of both maps were simplified to a common ten-class legend considered adequate for the purposes of this study:

1. Non combustible areas (5.3\% of study area): urban areas, dunes and water bodies; these were not included in the analysis.

2. Annual crops (25.4\% of study area): mainly composed of dry crops, irrigated crops, and diverse agriculture mosaics dominated by annual crops and natural pastures.

3. Permanent crops ( $8.4 \%$ of study area): mainly composed of olive groves, vineyards and orchards. 
4. Agro-forestry systems (5.2\% of study area): composed of a mixture of annual crops and trees, mainly holm oak (Quercus ilex), cork oak (Quercus suber), olive tree (Olea europaea) and other unspecified broadleaved trees.

5. Shrublands ( $28.5 \%$ of study area): mainly low shrublands but also tall shrublands, degraded or transitional forest, shallow cut or recently burned forests and sclerophyllous vegetation.

6. Conifer forests ( $10.1 \%$ of study area): mainly composed of maritime pine (Pinus pinaster) plantations.

7. Eucalyptus forests (1.9\% of study area): mainly Eucalyptus globulus plantations.

8. Broadleaved forests (6.0\% of study area): mainly cork oak and holm oak, but also mixed cork and holm oak, other oaks (Quercus robur and $Q$. pyrenaica) and unspecified broadleaves.

9. Mixed conifer and eucalyptus forests ( $4.8 \%$ of study area): composed almost totally of mixed maritime pine and eucalyptus, with pines dominant ( $\sim 70 \%$ ) over eucalyptus.

10. Mixed forests of broadleaved trees and conifers (or eucalyptus) ( $4.4 \%$ of study): mostly mixed broadleaved/conifers but also a few mixed broadleaved/eucalyptus forests. The main species combinations are maritime pine + cork oak, maritime pine + other oaks, stone pine + other unspecified broadleaved and stone pine + cork oak.

We assumed that major land cover changes during the two year period considered for analyses (1990 and 1991) were due to wildfires, so the 1991 land cover map was updated by assigning previously burned areas to the shrubland category, the most likely vegetation physiognomy in burned patches. The implication of this assumption is that the value for the selection ratios for shrublands in 1991 may have been lowered if fires did not occur in previously burned areas that we have categorized as shrublands.

\subsection{Slope and aspect maps}

Slope and aspect maps were obtained from a Digital Terrain Model with a spatial resolution of $90 \mathrm{~m}$ (DTM 90) available in internet (NASA, 2004), using simple operations of spatial analysis over the elevation matrix. Each map was classified in five classes; in the slope map we used the categories $0-5 \%, 5-10 \%, 10-15 \%$, $15-25 \%,>25 \%$ and in the aspect map we used the categories Flat terrain, north $\left(315-45^{\circ}\right)$, east $\left(45-135^{\circ}\right)$, south $\left(135-225^{\circ}\right)$ and west $\left(225-315^{\circ}\right)$.

\subsection{Fire data}

The location and size of burned areas during the period 1990-1991 were estimated by semi-automated processing of Landsat 5 Thematic Mapper satellite images, with a minimum-mapping unit of 5 ha (Pereira and Santos, 2003; Moreira et al., 2009). A total of 1382 burned patches larger than 5 ha were considered for analysis. As we were interested in regional variations in fire occurrence patterns, each fire was classified into one of the 3 ecological regions.

\subsection{Fire proneness of different land cover and topographic categories}

The methodology used to describe fire occurrence patterns was based on the computation of selection ratios, a methodology originally proposed for the study of resource selection by animals (Manly et al., 1993) and transposed to application in fire research by Moreira et al. (2001, 2009). The selection ratio $\left(w_{i}\right)$ for a given land cover or topographic class $i$ is an index of selection estimated as $w_{i}=o_{i} / \pi_{i}$ (Manly et al., 1993), where $o_{i}$ is the proportion of burned patch belonging to class $i$ (estimated from the area consumed by fire) and $\pi_{i}$ is the proportion of available area belonging to class $i$ (estimated from the area in a surrounding buffer). If a given class is used in proportion to its availability, then $w=1$. If $w>1$ the class is used more than expected by chance. If $w<1$, the class is used less than expected by chance. For determining availability $\left(\pi_{i}\right)$ we created circular buffers centred on the patch centroid coordinates and with an area equal to the maximum fire size in the respective ecological region. We assumed a circular buffer because, in the absence of fuel, climate and topography effects, the shape of a burned area would be a circle (Ventura and Vasconcelos, 2006), so this would be the best shape for testing against the null hypothesis of no land cover or topographic effects on fire selection patterns. For further details see Moreira et al. (2009). We used selection ratios to characterize the different classes of the three variables under study (land cover, slope and aspect) by individual fires. A few outliers $(n=19)$ were detected through box-plot inspection of the selection ratios for each variable, corresponding to atypical situations where the values were too high. In the subsequent analyses these fires were excluded. Values for each land cover and topographic category were then averaged across fires and the respective confidence intervals (95\%) were estimated. Differences between selection ratios for different classes were considered statistically significant when there was no overlap between the respective confidence intervals. Similarly, when the confidence interval did not include $w_{i}=1$, the class was considered significantly more or less used than expected by chance. In order to identify regional differences in fire occurrence patterns, the average ratios and confidence intervals for each class were compared across regions.

\subsection{Exploring relationships between topographical variables and land cover: could differences in selection ratios for topography be explained by land cover?}

We used two different methods to explore the potential interdependence among land cover and topographic features. First, we assessed the land cover composition for each slope and aspect category in the whole study area. Based on the average selection rations estimated for each of the land covers we then estimated a weighted fire proneness index for each topographic category. This index weighted the relative abundance of each land cover in each topographic category by its selection ratio, obtaining a single value that indicated the fire proneness of the slope and aspect class, as assessed from land cover composition. We then assessed whether the obtained index, derived from land cover, was correlated with the selection ratio directly estimated for each topographic category, using the Spearman rank correlation (Sokal and Rohlf, 1995). The second method simply compared the frequency of burned land cover categories across topographic categories, using a G-test of independence (Sokal and Rohlf, 1995) to test the null hypothesis that the proportion of burned area, for a given land cover class, was independent of aspect or slope. The tendency for specific topographic categories to systematically have higher or lower proportion of burned land cover across land cover classes was tested using the Friedman's test (Siegel and Castellan, 1988).

\section{Results}

\subsection{Fire occurrence patterns}

During the study period 1382 fires burned ca 55,739 ha in northern Portugal. Of this total number, 891 fires occurred in 1990 and 491 in 1991. The average size of burned patches was ca. 40 ha and the biggest fire burned 1351 ha. Most fires occurred in NW Cismontano, although they were smaller than in the Alto Portugal and NE Transmontano (Table 1). 
Table 1

Summary statistics of fires per ecological region, during the period 1990-1991.

\begin{tabular}{|c|c|c|c|c|}
\hline Region & Number of fires & Total burned area (ha) & Average fire size (ha) & Median fire size (ha) \\
\hline NW Cismontano & 590 & 21363 & 36.2 & 16.8 \\
\hline Alto Portugal & 513 & 22288 & 43.4 & 18.7 \\
\hline NE Transmontano & 279 & 12087 & 43.3 & 20.0 \\
\hline
\end{tabular}

\subsection{Fire selection patterns}

Shrublands were the only land cover type that burned more than expected if fires occurred randomly in the landscape (Fig. 2), with the selection ratio $\left(w_{i}=2.5\right)$ indicating that this land cover burned in a average proportion 2.5 times more than the available proportion. Annual and permanent crops were the less fire prone. For the remaining land covers, there seemed to be a gradient of increasing susceptibility to fire from agro-forestry systems (less susceptible) to mixed forests of conifers (or eucalyptus) and broadleaves.

In relation to slope, fire proneness progressively increased from smaller slopes $\left(<5 \%, w_{i} \approx 0.5\right)$ to the steeper ones $\left(>25 \%, w_{i} \approx 1.3\right)$ (Fig. 2). Aspect classes largely burned in proportion to their abundance on the landscape, although the selection ratios were slightly less than one for south-facing slopes. Flat areas were much less likely to burn (Fig. 2).

The numerical values for all estimated selection ratios (pooled and divided by region) can be seen in Appendices 1 and 2 .

\subsection{Regional variations in fire selection patterns}

Selection ratios varied among regions for land cover but not for topography (Fig. 3). In fact, for both slope and aspect, the error bars for each class overlapped across regions. However, for land cover, significant differences emerged. Although shrublands were the only class for which the proportion burned was higher than the proportion available, the average selection ratio of this land cover in the NW Cismontano almost doubled the values of Alto Portugal and NE Transmontano. Selection ratios were lower inland (that is, along the gradient NW Cismontano to NE Transmontano) for mixed conifer and eucalyptus forests and eucalyptus forests. In contrast, other land covers increased their selection ratios inland, namely broadleaved forests, mixed forests of broadleaved and conifers or eucalyptus, annual crops and agro-forestry systems. For the remaining land covers, namely conifer forests and permanent crops, a trend across regions was not so evident.

\subsection{Exploring relationships between topographical variables and land cover}

There was a strong positive correlation between the weighted fire proneness index estimated from land cover and the average selection ratio directly estimated (shown in Fig. 2) for the five slope categories $\left(r_{\mathrm{s}}=1.0, n=5, P<0.01\right)$. For aspect, there was also a positive correlation between observed selection ratios and estimated fire proneness index but it was not significant $\left(r_{\mathrm{S}}=0.308, n=5\right.$, $P=0.302$ ).

The proportion of burned area was not independent of slope for any land cover category $(G$-tests, $P<0.01)$. In fact, the proportion of area burned increased with slope for most land covers (Fig. 4), and this pattern was consistent across cover types (Friedman test, $\chi^{2}=26.9$, d.f. $\left.=4, P<0.001\right)$. The same result was observed for aspect, were only for eucalyptus the proportion of burned area was independent of the aspect category ( $G$-test, $G=22.9$, d.f. $=4$, $P=0.236$ ). For most land covers, the proportion of burned area was smaller in flat areas and higher in slopes directed to East or North (Fig. 5) (Friedman test, $\chi^{2}=19.7$, d.f. $=4, P=0.01$ ).
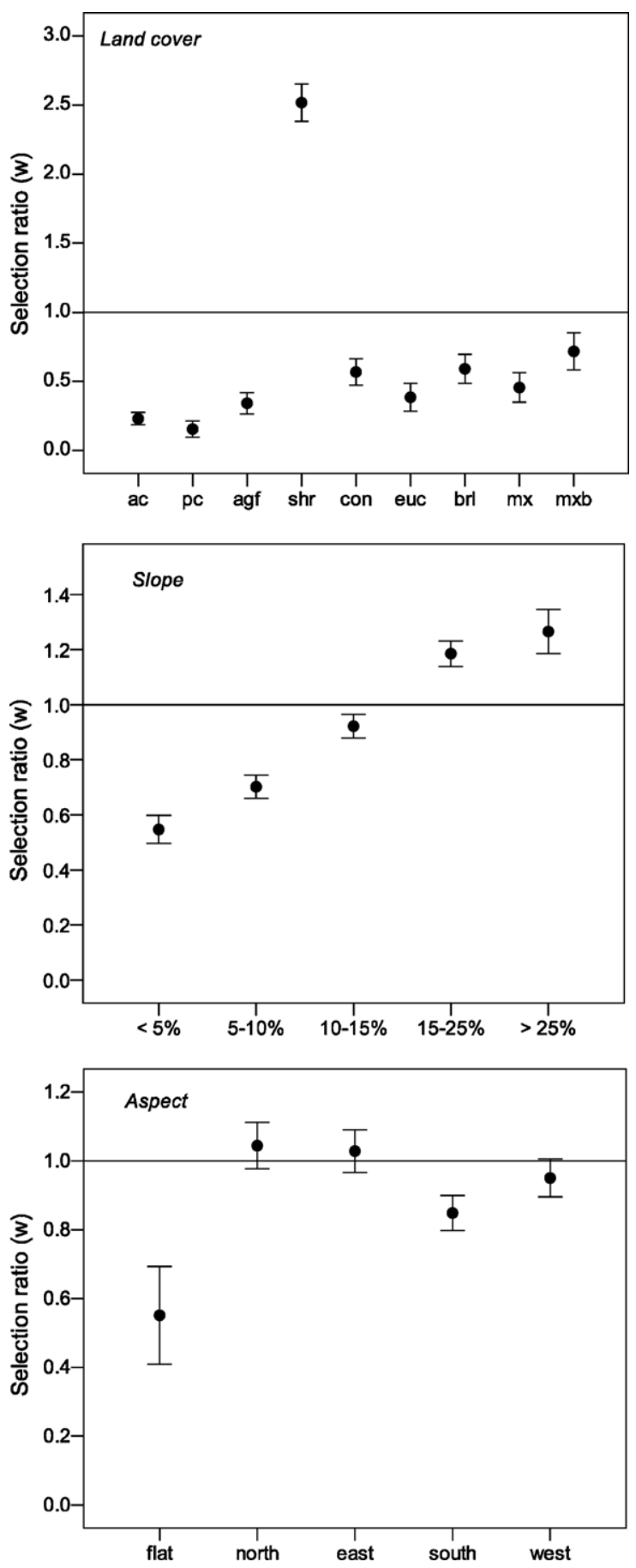

Fig. 2. Average selection ratios $(w)$ with $95 \%$ confidence intervals for land cover slope and aspect in the study area. Abbreviations for land cover: ac - annual crops; pc - permanent crops; agf - agro-forestry systems; shr - shrublands; con - conifer forests; euc - eucalyptus forests; brl - broadleaved forests; $\mathrm{mx}$ - mixed conifer and eucalyptus forests; mxb - mixed forests of broadleaved and conifer, or broadleaved and eucalyptus. 

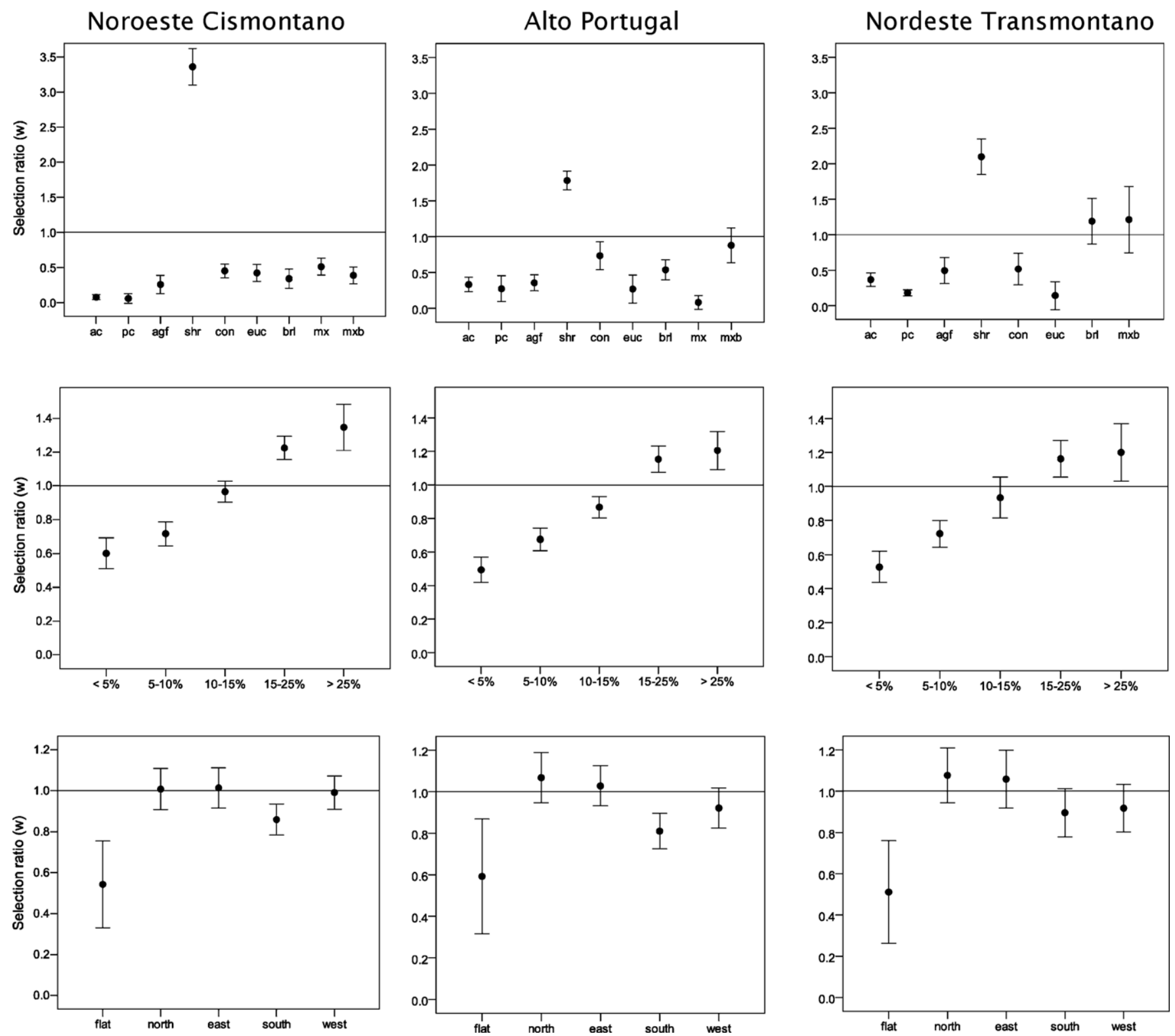

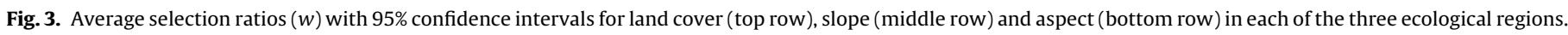

\section{Discussion}

\subsection{Overall fire selection patterns}

The analysis of fire selection patterns confirmed the selective character of fire regarding land cover, and results were in line with previous studies (e.g. Nunes et al., 2005; Moreira et al., 2009). Shrublands were the more fire prone land cover, and agricultural areas (annual and permanent crops), together with agro-forestry systems, were the less susceptible land covers. For croplands, this pattern may be explained by their low combustibility, due to the usually low fuel load and high moisture content (mainly in irrigated crops). In addition, most of these agricultural areas are closer to urban areas, thus fire detection is quicker and fire fighting easier (Moreira et al., 2009). Shrublands, in contrast, are given the lowest priority for fire fighting (they are the less valuable land cover), and probably have also a larger number of ignitions (e.g. burning to creating pastures for livestock) and a higher rate of fire spread. Finally, they were the most common land cover type in steeper slopes where the rate of fire spread is even higher (Rothermel, 1983). All these factors probably contribute to the high fire susceptibility of this land cover.

To the best of our knowledge this study applied for the first time the selection ratio approach to topographic variables. Despite the lack of independence between topography and land cover, which hinders the interpretation of the patterns found, the selection ratios for slope revealed a strong selectivity pattern, with increasing fire proneness in steeped slopes. This can be explained by the fact that fires spread most rapidly uphill on steep slopes, where the higher incident radiation promotes the fuel ignition (Rothermel, 1983). Mermoz et al. (2005) also found that fires were more likely to burn on steep slopes. An alternative explanation is that the land covers most likely to burn are more common on steep slopes (see Section 4.3). Selection patterns for aspect showed a weak selectivity, with only flat areas being clearly avoided by fire. In southern slopes, however, there was a trend towards lower fire proneness. Previously, Nunes (2004) found that fire likelihood varied with aspect, namely in the NW Cismontano and NE Transmon- 


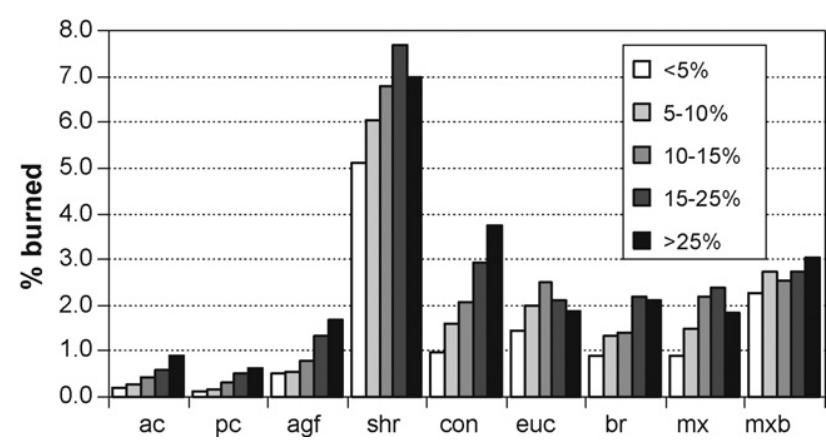

Fig. 4. Proportion of the area of a given land cover type burned, for each slope category. Abbreviations for land cover type: ac - annual crops; $\mathrm{pc}$ - permanent crops; agf - agro-forestry systems; shr - shrublands; con - conifer forests; euc - eucalyptus forests; brl - broadleaved forests; $\mathrm{mx}$ - mixed conifer and eucalyptus forests; mxb - mixed forests of broadleaved and conifer, or broadleaved and eucalyptus.

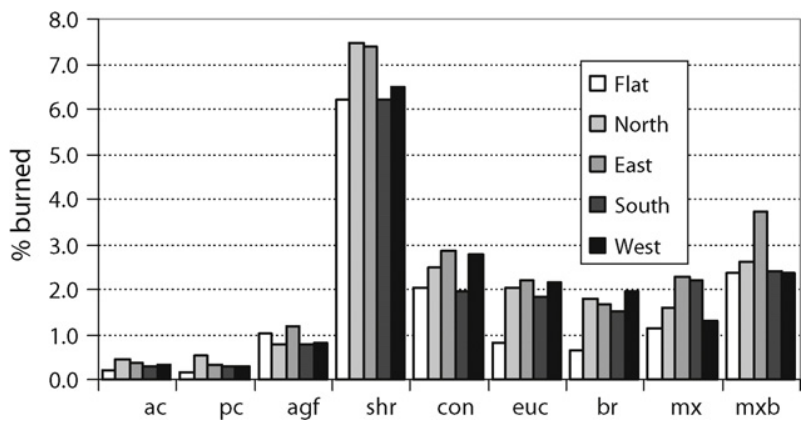

Fig. 5. Proportion of the area of a given land cover type burned, for each aspect category. Abbreviations for land cover type: ac - annual crops; $\mathrm{pc}$ - permanent crops; agf - agro-forestry systems; shr - shrublands; con - conifer forests; euc - eucalyptus forests; brl - broadleaved forests; $\mathrm{mx}$ - mixed conifer and eucalyptus forests; mxb - mixed forests of broadleaved and conifer, or broadleaved and eucalyptus.

tano regions, where northerly slopes were more prone to fire than southerly ones. So, the patterns found in northern Portugal contrast with other studies that showed that dryer and warmer aspects (xeric), southern aspects in our case, are usually more prone to fire (Mermoz et al., 2005; Heyerdahl et al., 2001; González et al., 2005). Again, one alternative explanatory hypothesis was that land covers more susceptible to fire are less frequent in southern slopes (see Section 4.3). For flat areas, the clear avoidance by fire may also be explained by the null slope in these areas.

\subsection{Regional variations in fire selection patterns}

Regional variations in selection patterns were obvious in the case of land cover. Moreira et al. (2009) addressed, at the country level, the role of different drivers shaping the geographical variation in selection patterns for land cover, including ignition patterns, climate, agro-forestry management, forest species composition, fire fighting strategy, and the regional availability of land cover categories. Within northern Portugal, the higher selectivity for croplands as we move from the seaside (NW Cismontano) to the interior (NE Transmontano) should be related to mainly climate (getting drier and hotter as we go inland) and crop management (more irrigated crops in NW Cismontano versus dry crops in NE Transmontano). For forests, changes in climate are also accompanied by changes in species composition: broadleaved forests showed higher susceptibility from the coast, where deciduous species (e.g. Quercus robur and Q. pyrenaica) are more common, towards the inland, where evergreen species $(Q$. rotundifolia and Q. suber) are predominant. The latter are probably more prone to fire as they present lower moisture content compared with the broadleaved deciduous species (Moreira et al., 2009). For shrublands, according to Moreira et al. (2009) the higher precipitation in the NW Cismontano increases the productivity and may generate higher fuel loads in shrublands. Additionaly, traditional shrubland burning for rangeland management is more common in western regions (Moreira et al., 2009).

The absence of regional variations in the selection patterns for slope and aspect suggests that they are ruled by drivers, which are similar across the three regions. At least for slope this should be expected, as the physical rules ruling their effects on fire behaviour are not expected to change geographically.

\subsection{Relationships between land cover and topography in explaining fire selection patterns}

We found that the observed fire selection patterns for the different slope categories could be explained by land cover, i.e., land cover types more prone to fire were more common on steeper slopes. For example, the proportion of area occupied with the fire-preferred shrublands and conifer forests increased with slope, whereas the proportion of the fire-avoided annual and permanent crops, more common on lowland flat areas, decreased with slope. But on the other hand, we also found a slope effect irrespective of land cover, in which susceptibility to fire increases with slope for most land cover types. This suggests a double mechanism by which fire spreads preferably in steeper slopes because of both the physical effect of incident radiation (Rothermel, 1983) and the occurrence of more fire-prone land covers. For aspect, a significant trend for more fire-prone land covers to occur in aspects with higher selection indices was not found. So, with the exception of the low preference for flat areas, which can be explained by the slope effect, it is difficult to find an explanation for the trend towards the lower selection index in southern slopes, which are expected to be drier and hence more fire prone. One possibility was that slopes differed in their occurrence in different aspects, i.e., steeper slopes occurring on southern aspects. But that was not the case, as the proportion of slopes over $15 \%$ was not higher in south aspects (37\%), compared to other orientations (41-45\%). Finally, one hypothesis that should be addressed in future studies is that other driver of fire spread, the predominant wind direction, may explain the observed pattern. The dominant winds in the region, during summer months, come from the north to northwestern quadrants (Ribeiro et al., 1987), but local variations can cause a large variability in this pattern.

\section{Conclusions}

This research showed that there were regional variations in the fire proneness of different land cover types in northern Portugal. In contrast, there were no variations in fire susceptibility of different slope or aspect categories. We confirmed the importance of slope in determining fire selectivity, not only because of more fire-prone land covers being associated to steeper slopes, but also because of the physical effect of slope on fire behaviour, which increased fire proneness in steeper slopes for all land covers. These results have obvious implications for landscape planning, in particular for landscape prognosis (sensu Leitão and Ahern, 2002). One of the landscape-level applications of these results is in the definition of landscape-scale fuel breaks. These can be implemented with several objectives including (a) effectively breaking up the continuity of hazardous fuels across a landscape, with the objective of reducing the occurrence of large wildfires, (b) reducing the intensity of wildfires, providing broad zones within which fire fighters can conduct suppression operations more safely and efficiently, (c) providing strips to facilitate subsequent area-wide fuel treatments, and (d) 
providing various non fire-related benefits (e.g. habitat diversity, landscape scenery) (e.g. Weatherspoon and Skinner, 1996; Agee et al., 2000; Cumming, 2001). Thus, when comparing alternatives for the location of fuel breaks, suitable land covers on suitable topographic categories could be used as a basis for deciding on the best location. Of course, these land covers could also be promoted in the wider landscape (block treatments) to reduce fire hazard at landscape level. In terms of landscape planning for reducing fire hazard, these results suggest that priority areas to be used as, or promoted in, landscape-scale fuel breaks should include agricultural areas (particularly if they have irrigated crops) in flat slopes. Agricultural policies should be designed and implemented with reducing fire hazard objectives in mind.

\section{Acknowledgments}

This research was carried out within the scope of projects "FFP Recuperação de áreas ardidas", financed by IFADAP/INGA and FIRELAND (Project PTDC/AGR-CFL/104651/2008). It was also supported by the "Programa de Fornecimento de Informação Geográfica para Investigação, Ensino e Edição" from the Instituto Geográfico Português. Pedro Vaz was funded by Fundacão para a Ciência e a Tecnologia (PhD grant SFRH/BD/45490/2008).

\section{Appendix 1.}

\begin{tabular}{lll}
\hline & Mean & Std \\
\hline Land cover & & \\
ac & 0.23 & 0.854 \\
pc & 0.16 & 0.923 \\
agf & 0.34 & 1.484 \\
shr & 2.52 & 2.566 \\
con & 0.57 & 1.766 \\
euc & 0.39 & 1.188 \\
brl & 0.59 & 1.921 \\
mx & 0.46 & 1.232 \\
mxb & 0.72 & 2.448 \\
Slope & & \\
$<5 \%$ & 0.55 & 0.969 \\
$5-10 \%$ & 0.70 & 0.786 \\
$10-15 \%$ & 0.92 & 0.811 \\
$15-25 \%$ & 1.19 & 0.885 \\
$>25 \%$ & 1.27 & 1.503 \\
Aspect & & \\
Flat & 0.55 & 2.528 \\
North & 1.04 & 1.275 \\
East & 1.03 & 1.169 \\
South & 0.85 & 0.969 \\
West & 0.95 & 1.041 \\
\hline
\end{tabular}

Mean and standard deviation of selection ratios for land cover, slope and aspect categories in northern Portugal. Abbreviations for land cover: ac - annual crops; pc - permanent crops; agf - agro-forestry systems; shr - shrublands; con-conifer forests; euc - eucalyptus forests; brl - broadleaved forests; $\mathrm{mx}$ - mixed conifer and eucalyptus forests; mxb - mixed forests of broadleaved and conifer, or broadleaved and eucalyptus.

\section{Appendix 2.}

\begin{tabular}{|c|c|c|c|c|c|c|}
\hline & \multicolumn{2}{|c|}{ Noroeste cismontano } & \multicolumn{2}{|c|}{ Alto Portugal } & \multicolumn{2}{|c|}{ Nordeste transmontano } \\
\hline & Mean & Std & Mean & Std & Mean & Std \\
\hline \multicolumn{7}{|c|}{ Land cover } \\
\hline $\mathrm{ac}$ & 0.08 & 0.431 & 0.33 & 1.163 & 0.37 & 0.808 \\
\hline $\mathrm{pc}$ & 0.06 & 0.711 & 0.27 & 1.463 & 0.18 & 0.335 \\
\hline agf & 0.26 & 1.601 & 0.35 & 1.290 & 0.50 & 1.551 \\
\hline shr & 3.36 & 3.189 & 1.78 & 1.491 & 2.10 & 2.100 \\
\hline con & 0.45 & 1.217 & 0.73 & 2.219 & 0.52 & 1.816 \\
\hline euc & 0.42 & 1.270 & 0.27 & 0.775 & 0.14 & 0.582 \\
\hline brl & 0.34 & 1.651 & 0.54 & 1.581 & 1.19 & 2.701 \\
\hline $\mathrm{mx}$ & 0.51 & 1.302 & 0.08 & 0.399 & - & - \\
\hline $\mathrm{mxb}$ & 0.39 & 1.459 & 0.88 & 2.635 & 1.21 & 3.624 \\
\hline
\end{tabular}

\begin{tabular}{|c|c|c|c|c|c|c|}
\hline & \multicolumn{2}{|c|}{$\begin{array}{l}\text { Noroeste } \\
\text { cismontano }\end{array}$} & \multicolumn{2}{|c|}{ Alto Portugal } & \multicolumn{2}{|c|}{ Nordeste transmontano } \\
\hline & Mean & Std & Mean & Std & Mean & Std \\
\hline \multicolumn{7}{|l|}{ Slope } \\
\hline$<5 \%$ & 0.60 & 1.1183 & 0.49 & 0.874 & 0.53 & 0.772 \\
\hline $5-10 \%$ & 0.72 & 0.8573 & 0.68 & 0.766 & 0.72 & 0.654 \\
\hline $10-15 \%$ & 0.97 & 0.7646 & 0.87 & 0.734 & 0.93 & 1.014 \\
\hline $15-25 \%$ & 1.22 & 0.8548 & 1.15 & 0.905 & 1.16 & 0.910 \\
\hline$>25 \%$ & 1.35 & 1.7008 & 1.21 & 1.302 & 1.20 & 1.381 \\
\hline \multicolumn{7}{|l|}{ Aspect } \\
\hline Flat & 0.54 & 2.555 & 0.59 & 2.763 & 0.51 & 2.088 \\
\hline North & 1.01 & 1.240 & 1.07 & 1.389 & 1.08 & 1.123 \\
\hline East & 1.01 & 1.209 & 1.03 & 1.113 & 1.06 & 1.189 \\
\hline South & 0.86 & 0.938 & 0.81 & 0.988 & 0.90 & 0.999 \\
\hline West & 0.99 & 1.008 & 0.92 & 1.110 & 0.92 & 0.978 \\
\hline
\end{tabular}

Mean and standard deviation of selection ratios for land cover, slope and aspect categories for the three studied regions. Abbreviations for land cover: ac - annual crops; pc - permanent crops; agf - agro-forestry systems; shr - shrublands; con - conifer forests; euc - eucalyptus forests; brl - broadleaved forests; mx - mixed conifer and eucalyptus forests; mxb - mixed forests of broadleaved and conifer, or broadleaved and eucalyptus.

\section{References}

Agee, J.K., Bahro, B., Finney, M.A., Omi, P.N., Sapsis, D.B., Skinner, C.N., Wagtendonk, J., Weatherspoon, P., 2000. The use of shaded fuelbreaks in landscape fire management. For. Ecol. Manage. 127, 55-66.

Albuquerque, J.P.M., 1985. Regiões Naturais, Sub-regiões e Agrotipos de Portugal. Scale 1/500 000 (Natural Regions, Sub-regions and Agricultural Types in Portugal). Direcção Geral dos Serviços Agrícolas, Lisbon (in Portuguese).

APA, 2008. Atlas do Ambiente Digital (Environmental Digital Atlas). Portuguese Environment Agency (APA), Retrieved April 10, 2008, from http://www2.apambiente.pt/atlas/est/index.jsp (in Portuguese).

Bajocco, S., Ricotta, C., 2008. Evidence of selective burning in Sardinia (Italy): which land-cover classes do wildfires prefer? Landscape Ecol. 23, 241-248.

Catry, F., Rego, F., Bação, F., Moreira, F., 2009. Modelling and mapping wildfire ignition risk in Portugal. Int. J. Wildland Fire 18, 921-931.

Costa, J.C., Aguiar, C., Capelo, J.H., Lousã, M., Neto, C., 1998. Biogeografia de Portugal continental (Biogeography of Continental Portugal)). Quercetea 1, 5-56 (in Portuguese).

Cumming, S.G., 2001. Forest type and wildfire in the Alberta boreal mixedwood: what do fires burn? Ecol. Appl. 11, 97-110.

González, J.R., Palahí, M., Pukkala, T., 2005. Integrating fire risk considerations in forest management planning in Spain-a landscape level perspective. Landscape Ecol. 20, 957-970.

Hann, W.J., Bunnell, D., 2001. Fire and land management planning and implementation across multiple scales. Int. J. Wildland Fire 10, 389-403.

Heyerdahl, E.K., Brubaker, L.B., Agee, J.K., 2001. Spatial controls of historical fire regimes: a multiscale example from the interior west, USA. Ecology 82, $660-678$.

IGP, 2008. Carta de Ocupação do Solo - COS $90(1: 25,000)$ (Land cover map COS 90). Portuguese Geographic Institute (IGP), Retrieved April 10, 2008, from http://www.igeo.pt/produtos/CEGIG/COS.htm (in Portuguese).

IGP, 2008. Carta CORINE Land Cover (1985-1987) (CORINE Land Cover Map (1985-1987)), first ed. Portuguese Geographic Institute (IGP), Retrieved April 10, 2008, from www.igp.pt (in Portuguese).

Krumel, J.R., Gardner, R.H., Sugihara, G., O’Neill, R.V., Coleman, P.R., 1987. Landscape patterns in a disturbed environment. Oikos 48, 321-324.

Leitão, A.B., Ahern, J., 2002. Applying landscape ecological concepts and metrics in sustainable landscape planning. Landscape Urban Plan. 59, 65-93.

Manly, B., McDonald, L.L., Thomas, D.L., 1993. Resource Selection by Animals: Statistical Design and Analysis for Field Studies. Chapman and Hall, London, UK.

Mermoz, M., Kitzberger, T., Veblen, T.T., 2005. Landscape influences on occurrence and spread of wildfires in Patagonian forests and shrublands. Ecology 86, 2705-2715.

Moreira, F., Rego, F., Ferreira, P., 2001. Temporal (1958-1995) pattern of change in a cultural landscape of northwestern Portugal: implications for fire occurrence. Landscape Ecol. 16, 557-567.

Moreira, F., Vaz, P.J.G., Catry, F.X., Silva, J.S., 2009. Regional variations in wildfire susceptibility of land cover types in Portugal: implications for landscape management to minimize fire hazard. Int. J. Wildland Fire 18, 563-574.

NASA, 2004. Digital terrain model. National Aeronautics and Space Administration (NASA), National Imagery and Mapping Agency (NIMA). German space agency (DLR), Italian space agency (ASI), ftp://e0srp01u.ecs.nasa.gov/srtm.

Nunes, M.C., 2004. A selectividade do fogo face ao coberto do solo e à topografia[[nl]]Fire selectivity in relation to land cover and topography). PhD Thesis. Cartography Center, Institute for Cientific and Tropical Investigation, Lisbon (in Portuguese).

Nunes, M.C., Vasconcelos, M.J., Pereira, J.M., Dasgupta, N., Alldredge, R.J., Rego, F.C., 2005. Land cover types and fire in Portugal: do fires burn land cover selectively? Landsc. Ecol. 20, 661-673. 
Pereira, J.M., Carreiras, J.M., Silva, J.M., Vasconcelos, M.J., 2006. Alguns conceitos básicos sobre os fogos rurais em Portugal. In: Pereira, J.S., et al. (Eds.), Incêndios Florestais em Portugal - Caracterização, Impactes e Prevenção. ISAPress, Lisbon, Portugal, pp. 133-161 (in Portuguese).

Pereira, J.M., Santos, T.N., 2003. Fire Risk and Burned Area Mapping in Portugal. Direcção Geral das Florestas, Lisbon, Portugal.

Pereira, M.G., Trigo, R.M., Da Camara, C.C., Pereira, J.M., Leite, S.M., 2005. Synoptic patterns associated with large summer forest fires in Portugal. Agr. For. Meteorol. 129, 11-25.

Pickett, S.T., White, P.S. (Eds.), 1985. The Ecology of Natural Disturbance and Patch Dynamics. Academic Press, New York, USA

Rego, F., 1992. Land use changes and wildfires. In: Teller, A., Mathy, P., Jeffers, J.N.R. (Eds.), Responses of Forest Ecosystems to Environmental Changes. Elsevier Applied Science, London, UK, pp. 367-373.

Ribeiro, O., Lautensach, H., Daveau, S., 1987. Geografia de Portugal. II. O Ritmo Climático e a Paisagem. Edições João Sá da Costa, Lisboa, Portugal.

Rivas-Martínez, S., 1987. Memoria del Mapa de Series de Vegetación de España $(1: 400,000)$ (Maps of Vegetation Series in Spain). ICONA, Madrid (in Spanish).

Rivas-Martínez, S., Díaz, T.E., Fernández-González, F., Izco, J., Lousã, M., Penas, A., 2002. Vascular plant communities of Spain and Portugal. Addenda to the Syntaxonomical checklist of 2001. Itinera Geobotanica 15 (1), 5-432.

Rothermel, R. (1983). How to predict the spread and intensity of forest and range fires. USDA, Forest Service, Intermountain Forest and Range Experiment Station, General Technical Report INT-143.
Siegel, S., Castellan, N.J., 1988. Nonparametric Statistics for the Behavioral Sciences. McGraw-Hill, Inc., New York.

Silva, J.M., 1990. La gestion forestiére et la silviculture de prevention des espaces forestiers menacés par les incendies au Portugal (Forest management and preventive silviculture on areas with high fire risk in Portugal). Revue Forestière Française 40, 337-345 (in French).

Sokal, R.R., Rohlf, F.J., 1995. Biometry: The Principles and Practice of Statistics in Biological Research, third ed. W.H. Freeman, New York.

Turner, M.G., Gardner, R.H., Dale, V.H., O’Neill, R.V., 1989. Predicting the spread of disturbance across heterogeneous landscape. Oikos 55, 121-129.

Turner, M.G., Dale, V.H., 1990. Modeling landscape disturbance. In: Turner, M.G., Gardner, R.H. (Eds.), Quantitative Methods in Landscape Ecology. SpringerVerlag, New York, pp. 323-351.

Turner, M.G., Dale, V.H., 1991. Modelling landscape disturbance. In: Turner, M.G., Gardner, R.H. (Eds.), Quantitative Methods in Landscape Ecology. The Analysis and Interpretation of Landscape Heterogeneity. Springer Verlag, New York, USA pp. 323-351.

Ventura, J., Vasconcelos, M.J.,2006. O fogo como processo físico-químico e ecológico. In: Pereira, J.S., Pereira, J.M.C., Rego, F.C., Silva, J.M.N., Silva, T.P. (Eds.), Incêndios Florestais em Portugal. ISA Press, Lisboa, Portugal, pp. 93-113.

Weatherspoon, C.P., Skinner, C.N., 1996. Landscape-Level Strategies for Forest Fue Management. In Sierra Nevada Ecosystem Project: Final Report to Congress, II: Assessments, Scientific Basis for Management Options. Centers for Water and Wildland Resources, Water Resources Center Report No. 37, Davis, USA University of California, 1471-1492. 